\title{
Determinants of seed variety selection among cowpea farmers in Osun state, Nigeria
}

\begin{abstract}
Appropriate seed selection enhances farm productivity, profitable production system and optimizes the cost of cultivation. The study analysed the socio-economic factors influencing farmers' choices of cowpea seed for cultivation in Osun State. Cross-sectional survey data of four local government areas of Osun State was obtained. Evidence from Multinomial Logit showed that years of farmer's education, experience in cowpea farming methods, and were statistically significant associated with farmers' choices relative to the reference group. The finding indicates a need to consider farmers economic climate in seed technology development process.
\end{abstract}

Key words: seed technology, adoption, cowpea, multinomial logit

\author{
Volume 2 Issue 4 - 2018
}

\section{Baruwa Olayinka Isiaka}

Department of Agricultural Economics, Obafemi Awolowo University, Nigeria

Correspondence: Baruwa Olayinka Isiaka, Department of Agricultural Economics, Obafemi Awolowo University, lle Ife. Nigeria, Email aragbon2005@yahoo.co.uk

Received: May 30, 2018 | Published: July 02, 2018

\section{Introduction}

The importance of cowpea (Vigna unguiculata L. Walp) in bridging the food gap in Nigeria cannot be overemphasized. Nutritionally, cowpea is a good source of protein for both human and livestock. It is also a source of income to farmers, serves as nitrogen fixation and cover crops thus improving the soil fertility of the marginal lands. ${ }^{1}$ The prospect for reducing hunger, malnutrition and food insecurity through increase in cowpea productivity is significant. ${ }^{2}$ In other to realise the goal, there is need to increase the output of cowpea. Among ways of achieving the goal is selection of appropriate seed input to enhance farm productivity, profitable production system and optimal return to farmers. For sustainability of smallholder farmers, increased use of inputs (seeds, chemicals and fertilizers) is of paramount importance. In sub-Saharan Africa, purchased input use is very low and static over the last 20 years or so. ${ }^{3}$

Due to strong correlation between farmers' output and the input utilization, there is need to improve the hybrid seed utilization of the smallholder farmers over time and there ought to exist a relationship between the input utilization of the farmer and socio-economic factors, ${ }^{4}$ which is significant in the micro environment which the farmer operates. This study therefore examined the socio-economic factors influencing the selection of seed varieties by cowpea farmers in order for research and extension to take adequate advantage of the socio-economic environment of the farmers, their cultural diversities and uniqueness in enhancing farm productivity, profitable production system and optimal return to farmers.

\section{Materials and methods}

The area of study is Osun State, Nigeria, and lies within latitude $7.0^{\circ}$ and $9.0^{\circ} \mathrm{N}$, and longitude $2.8^{\circ}$ and $6.8^{\circ} \mathrm{E}$. with land area of $8,602 \mathrm{~km}^{2}$. The mean rainfall ranges from $1125 \mathrm{~mm}$ to $1475 \mathrm{~mm}$ while the average annual temperature ranges from $27.2^{\circ} \mathrm{C}$ to $39.0^{\circ} \mathrm{C}$. Majority of the respondents are farmers, both food crops and permanent crops were grown either as mixed or intercropped. Random sampling technique was used to collect a sample of 200 cowpea farmers in four selected areas of Osun State, Southwestern Nigeria, for the 2013/2014 agricultural growing seasons. In each of the four purposively selected Local Governments Areas notable for cowpea production in the state, 50 cowpea farmers were selected. A structured questionnaire was used to collect information on input-output cowpea production activities. Descriptive statistics was used to describe socio-economic characteristics of the respondents while multinomial logit was used to establish relationship to likelihood of selection of cowpea seed varieties and socio-economic factors affecting it. The Multinomial Logit Model (MNLM) was used for analyzing unordered qualitative variables. It deals with truly nominal and mutually exclusive categories. Suppose a dependent variable (DV), $y$, has $\mathrm{m}$ categories that are $\mathrm{y}=1,2 \ldots \mathrm{m}$ with $\mathrm{P}_{1}, \mathrm{P}_{2} \ldots \mathrm{P}_{\mathrm{m}}$ as associated probabilities, such that $\mathrm{P}_{1}+\mathrm{P}_{2}+\ldots+\mathrm{P}_{\mathrm{m}}=1$. One value (typically the first, the last or the value with highest frequency) of the DV is designated as the reference category. The probability of membership in other categories is then compared to the probability of membership in the reference category. Consequently, for a DV with M categories, this requires the calculation of M-1 equations, one for each category relative to the reference category, to describe the relationship between the DV and the independent variables (IVs). The generalized form of probabilities for an outcome variable with $M$ categories is:

$$
\operatorname{Pr}\left(y_{i}=m \mid x_{i}\right)=P_{i m}=\frac{\exp \left({ }_{x_{i}} \beta_{m}\right)}{1+\sum_{m=2}^{m} \exp \left(x_{i} \beta_{m}\right)}
$$

$\operatorname{Pr}\left(y_{i}=m\right)$ is the probability of choosing either TVS variety, Oloyin, Ife Bimpe with Ife brown as the reference category.

$\mathrm{M}$ is the number of varieties in the choice set.

$\mathrm{m}=0$ is Ife brown

$\mathrm{X}_{\mathrm{i}}$ is a vector of the predictor (exogenous) social factors (variables)

$\beta_{\mathrm{m}}$ is a vector of the estimated parameters

For the reference category,

$$
\operatorname{Pr}\left(y_{i}=1 \mid x_{i}\right)=P_{i 1}=\frac{1}{1+\sum_{m=2}^{M} \exp \left(\mathrm{X}_{\mathrm{i}}, \beta_{\mathrm{m}}\right)}
$$

for $\mathrm{K}$ covariates, a total of $(\mathrm{K}+1) *(\mathrm{M}-1)$ parameters will be estimated.

The odds and odds-ratios for a variable with $\mathrm{M}$ categories and 
baseline, $\mathrm{M}=1$ :

$$
\begin{aligned}
& \frac{P_{i m}}{P_{i 1}}=\frac{\eta_{i m}}{\eta_{i 1}}=\exp \left(x_{i}, \beta_{m}\right) \rightarrow \log \frac{P_{i m}}{P_{i 1}}=x_{i}, \beta_{m} \\
& \log \frac{\left(P_{m} \mid X_{k}=1\right) \mid\left(P_{1} \mid X_{k}=1\right)}{\left(P_{m} \mid X_{k}=0\right) \mid\left(P_{1} \mid X_{k}=0\right)}=\beta_{m k} \\
& \log \frac{\left(P_{m} \mid X_{k}=X_{k}^{0}+1\right) /\left(P_{1} \mid X_{k}=X_{k}^{0}+1\right)}{\left(P_{m} \mid X_{k}=X_{k}^{0}\right) /\left(P_{1} \mid X_{k}=X_{k}^{0}\right)}=\beta_{m k}
\end{aligned}
$$

Specifically, the standard MNLM for model with $\mathrm{m}=6$ categories become

$$
\operatorname{Pr}\left(y_{i}=1 \mid x_{i}\right)=P_{i 1}=\frac{1}{1+\exp \left(x_{i}, \beta_{2}\right)+\exp \left(x_{i}, \beta_{n}\right)}=\frac{\eta_{i 1}}{\eta_{i 1}+\eta_{i 2}+\eta_{i 6}}
$$$$
\operatorname{Pr}\left(y_{i}=2 \mid x_{i}\right)=P_{i 2}=\frac{\exp \left(x_{i}, \beta_{m}\right)}{1+\exp \left(x_{i}, \beta_{2}\right)+\exp \left(x_{i}, \beta_{n}\right)}=\frac{\eta_{i 2}}{\eta_{i 1}+\eta_{i 2}+\eta_{i 6}}
$$

$$
\operatorname{Pr}\left(y_{i}=n \mid x_{i}\right)=P_{i n}=\frac{\exp \left(x_{i}, \beta_{n}\right)}{1+\exp \left(x_{i}^{\prime} \beta_{2}\right)+\exp \left(x_{i}, \beta_{n}\right)}=\frac{\eta_{i 6}}{\eta_{i 1}+\eta_{i 2}+\eta_{i 6}}
$$

\section{Empirical model}

The model is specified as:

$$
Y_{i}=\beta_{o}+\beta_{1} X_{1}+\beta_{2} X_{2}+\beta_{3} X_{3}+\beta_{4} X_{4}+\beta_{5} X_{5}
$$

Where $Y_{i}$, (dependent Variable) is the method of adaptation chosen by the farmer,

$\mathrm{X}_{\text {is }}$ (explanatory variables). $\mathrm{Y}_{\mathrm{i}}$ is defined as 1 for TVS variety, 2 for Ife brown (base outcome), 3 for 'Oloyin' and 4 for 'Ife Bimpe'. The independent variables are:

$$
\begin{aligned}
& X_{1=} \text { farmers' age (years) } \\
& X_{2}=\text { access to credit } \\
& X_{3=} \text { formal education (years) } \\
& X_{4=} \text { number of years of experience in farming } \\
& X_{5}=\text { farm size }
\end{aligned}
$$

\section{Results and discussion}

Mean age of the respondents was 45.4 implied that farmers were still in their active age bracket (Table 1). About 14.3 per cent had no formal education compared to 38.5 per cent who had primary education. However, majority $(97.2 \%)$ of the farmers were male. Years of education was statistically significant at $10 \%$ and positively related to TVS seed variety selection by farmers relative to 'Ife brown' which is the base outcome. Similarly, years of education ( $\mathrm{P}$ $\leq 0.05)$ and farming experience $(\mathrm{P} \leq 0.10)$ were significantly related to 'Oloyin' variety selection but found to be negative while age is the only significant variable influencing the decision to select 'Ife bimpe' by cowpea farmers (Table 2). However age is negative indicating that the variety appeals to younger farmers than older cowpea farmers. The significance of education follows a priori expectation, given that education is an important factor in technology adoption. Farming experience was also negative and significant. This implies that the decision to adopt improved cowpea seeds decreases as experience in farming, measured by the number of years put into farming activities increases. This is not in line with a priori expectation because more experienced farmers may have better skills and access to new information about improved technologies. This could be due to the fact that farmers become adapted to certain ways of doing things and the tendency to adopt a new innovation is always difficult.

Table I Socio-economic demographics of respondents

\begin{tabular}{llll}
\hline Item & Frequency & Distribution (\%) & Mean \\
\hline Education level & & \\
No formal schooling & 10 & 14.3 \\
Primary school & 27 & 38.5 \\
Secondary school & 22 & 31.5 \\
Post-secondary school & 11 & 15.7 \\
Age group & & \\
$21-29$ & 9 & 12.9 \\
$30-38$ & 10 & 14.3 \\
$39-47$ & 21 & 30 \\
$48-56$ & 19 & 27.1 \\
$57-65$ & 9 & 12.9 \\
66 and above & 2 & 2.8 \\
Sex & & 97.2 \\
Male & 68 & 2.8 \\
Female & 2 & 45.4 \\
\hline
\end{tabular}

Source- Field survey, 2014

Table 2 Determinants of seed variety selection by cowpea farmers

\begin{tabular}{lllll}
\hline Varieties & Variables & Coefficient & $\begin{array}{l}\text { Standard } \\
\text { error }\end{array}$ & $\mathbf{z}$ \\
\hline TVS & Age $\left(\mathrm{X}_{1}\right)$ & 0.022 & 0.039 & 0.57 \\
& Credit access & 15.22 & 1800.9 & 0.01 \\
& $\left(\mathrm{X}_{2}\right)$ & & & \\
& Farm size $\left(\mathrm{X}_{3}\right)$ & -0.33 & 0.43 & -0.77 \\
& Education $\left(\mathrm{X}_{4}\right)$ & 0.5296 & 0.316 & $1.73^{* *}$ \\
& Experience $\left(\mathrm{X}_{5}\right)$ & -0.09 & 0.075 & -1.22 \\
& Constant $(\beta)$ & -16.54 & 1800.92 & -0.01 \\
Ife brown (base & & & & \\
Outcome) & & & & \\
Oloyin & & -0.11 & -0.08 & -1.31 \\
& Age & 16.21 & 1800.927 & 0.01 \\
& Credit access & 1.15 & 1.134 & 1.02 \\
& Farm size & -1.5826 & 0.7938 & $-1.99 *$
\end{tabular}




\begin{tabular}{lllll} 
Table Continued & & & & \\
\hline Varieties & Variables & Coefficient & $\begin{array}{l}\text { Standard } \\
\text { error }\end{array}$ & $\mathbf{z}$ \\
\hline & Experience & -0.344 & 0.205 & $-1.67^{* *}$ \\
& Constant & -9.67 & 1800.93 & -0.01 \\
Ife Bimpe & & & & \\
& Age & -0.096 & 0.057 & $-1.68^{* *}$ \\
& Credit access & -0.676 & 3529.407 & 0 \\
& Farm size & -0.905 & 0.8655 & -1.05 \\
& Education & 0.215 & 0.3451 & 0.62 \\
& Experience & 0.114 & 0.088 & 1.29 \\
$\mathrm{LR} \mathrm{Chi}^{2}=$ & Constant & 3.73 & 3529.4 & 0 \\
40.35 & & & & \\
${\text { Prob }>\mathrm{Chi}^{2}=}=0.0019$ & & & \\
$\mathrm{R}^{2}=0.218$ & & & &
\end{tabular}

Source- Field survey, 2014

$* 5 \%$ level of significance, ${ }^{*}$ 1 $10 \%$ level of significance

\section{Summary conclusion and policy recommendations}

The study examined the socio-economic factors influencing the selection of seed varieties by cowpea farmers in Osun State, Southwest, Nigeria. The descriptive analysis of the socio economic characteristics of the respondents revealed that the respondents were young, averagely educated and comprising more men. Evidence from Multinomial Logit showed that years of farmers education, experience in cowpea farming methods, were statistically significant associated with farmers' choices relative to the reference group. However farmers' age was negative indicating that the variety appeals to younger farmers than older cowpea farmers. In conclusion, desirable increase in productivity, national and households' food security, reduction in hunger, poverty and malnutrition are products of improved agricultural technology adoption in developing countries, including Nigeria. From the findings, it was recommended that since socio-economic factors influencing the selection of seed varieties by cowpea farmers in Osun some policy should be put in place in form of enlightment campaign, toward increase in farmer's education. The implication of this is that costs of obtaining new technical and related information by the farmers will be reduced substantially when they can read and understand published materials and simplified farm journals which are increasingly becoming the modern vehicle of disseminating information.

\section{Acknowledgements}

None.

\section{Conflict of interest}

Author declares that there is no conflict of interest.

\section{References}

1. Fatokun AC. Breeding cowpea for resistance to insect pests; attempted crosses between cowpea and vigna vexillata. In : challenges and opportunities for enhancing sustainable cowpea production. Fatokun CA, Tarawali SA, Singh BB, editors. International Institute for Tropical Agriculture (IITA); Ibadan, Nigeria: 2002;52-61.

2. Coulibaly O, Lowenberg Debber J. The economics of cowpea in West Africa. In: Challenges and opportunities for enhancing sustainable cowpea production. Proceedings of the World Cowpea Conference III held at the International Institute of Tropical Agriculture (IITA); Ibadan, Nigeria: 2000.

3. Abayomi YA, Ajibade TV, Samuel OF, et al. Growth and yield responses of cowpea (Vigna unguiculata L. Walp) genotypes to nitrogen fertilizer (N.P.K.) application in the Southern Guinea Savannah zone of Nigeria. Asian Journal of Plant Sciences. 2008;7(2):170-176.

4. Nwagbo EC, Achoja FO. Correlates of sustainable fertilizer consumption among smallholder farmers: an econometric approach. A paper presented at the annual conference of Nigeria association of agricultural economists at the University of Nigeria; Nsukka: 2001. 